\title{
PERAN UMKM MENGHADAPI MEA 2015 MELALUI PELATIHAN BAHASA INGGRIS
}

\author{
Rianto Nurcahyo \\ Raja Halim Harahap \\ Didiet Gharnaditya
}

\begin{abstract}
Entering the era of globalization, better known as free market requires every individual to prepare reliable resources, especially in the field of Science and Technology. In order to master these demands, it is required adequate knowledge so that they can use it in dealing with the demands of a globalized world full of competition. In this regard, the role of the English language is required both in mastering communication technologies and to interact directly; moreover, the presence of the media especially the Internet will force people to learn English. As a means of global communication, English should be actively mastered both orally and in written. In an increasingly globalized business world, there are more local Indonesian companies entering into the world market, and growing number of international companies.

This research is an attempt to create the roles of exporters, especially the Micro, Small and Medium Enterprises (SMEs) through the products produced by the exporters themselves. Of the Indonesian export revenue number to other countries, the value of Indonesia's exports is relatively low, one of the constraints faced by exporters is in terms of the ability of a foreign language, namely English. Mastery of English is the main capital to open international trading communication.

This method is expected to eventually be able to provide additional knowledge and self-confidence for the exporters who want to market their products abroad, the title of this study is Preparing SMEs in facing AEC 2015 through English training program to obtain export market (Keywords: Training, Export, ASEAN, MEA)
\end{abstract}

Keywords: Training, Export, ASEAN, MEA

\section{PENDAHULUAN}

Memasuki tahun ini Indonesia dihadapkan oleh kesepakatan bersama di bidang ekonomi yaitu MEA (Masyarakat Ekonomi ASEAN) ,MEA merupakan sebuah gagasan dari anggota-anggota seluruh negara-negara ASEAN yang bertujuan untuk menciptakan pembangunan dinegara ASEAN dengan melakukan integrasi ekonomi yaitu aliran bebas barang dan jasa, investasi dan tenaga kerja terdidik antara Negara ASEAN, Indonesia dengan penduduknya lebih dari 200 juta yang terlampir data menurut United Nation, negara Indonesia berada ditingkat sebagai negara berkembang. Negara berkembang adalah negara yang sedang berupaya agar bisa menjadi sebagai negara maju dengan meningkatkan kesejahteraan rakyatnya dari berbagai sektor. 
Tabel 1

Tabel Perbandingan Jumlah Penduduk Negara

\begin{tabular}{|c|l|r|}
\hline No & \multicolumn{1}{|c|}{ Negara } & Jumlah Penduduk Total \\
\hline 1 & $\begin{array}{l}\text { Republik Rakyat } \\
\text { Cina }\end{array}$ & 1.306 .148 .035 \\
\hline 2 & India & 1.065 .070 .607 \\
\hline 3 & Amerika Serikat & 297.336 .946 \\
\hline 4 & Indonesia & 241.452 .952 \\
\hline 5 & Brasil & 184.101 .109 \\
\hline 6 & Pakistan & 159.196 .336 \\
\hline 7 & Rusia & 143.782 .338 \\
\hline 8 & Bangladesh & 141.340 .476 \\
\hline 9 & Nigeria & 137.253 .133 \\
\hline 10 & Jepang & 127.333 .002 \\
\hline
\end{tabular}

Sumber : CIA World Factbook 2004

Dari data diketahui bahwa Indonesia dengan jumlah penduduk no 4 di dunia berdasarkan CIA World Factbook 2004 akan menjadi sasaran perdagangan karena mempunyai potensi besar yang menjadi basis konsumsi. Dari gambaran ini dapat diketahui bahwa Indonesia memiliki strategi yang baik dan MEA 2015 menjadikan peluang besar bagi Indonesia untuk membangun perekonomian. Salah satu cara Indonesia membangun perekonomian dengan menambah sektor UMKM. Usaha Mikro Kecil dan Menengah (UMKM) memiliki peran yang sangat besar dalam perekonomian Indonesia. Adapun yang dimaksud dengan Usaha Menengah disini adalah usaha ekonomi produktif yang berdiri sendiri yang dilakukan oleh perseorangan atau badan usaha yang bukan merupakan anak perusahaan atau cabang perusahaan yang dimiliki, dikuasai atau menjadi bagian baik langsung maupun tidak langsung dengan usaha kecil atau besar dengan jumlah kekayaan bersih atau memiliki kekayaan bersih lebih dari 500 juta sampai dengan paling banyak 10 milliar tidak termasuk tanah dan bangunan atau memiliki hasil penjualan tahunan lebih dari Rp2.5 milliar sampai dengan paling banyak 50 milliar.

Peranan UMKM dalam perekonomian Indonesia pada PDB 2014, yaitu sebesar 57,9 persen dan kontribusi penyerapan tenaga kerja 97,2 persen. Adapun yang dimaksud dengan PDB (Produk Domestik Bruto) adalah semua barang dan jasa yang di produksikan dalam suatu Negara dalam jangka waktu tertentu (yang biasanya tahun). Untuk kawasan ASEAN sendiri, lebih dari 96 persen perusahaan di ASEAN adalah UKM dan kontribusi terhadap PDB sebesar 30-50 persen hal ini berdasarkan data dari Direktur Jenderal Industri Kecil dan Menengah Kementerian Perindustrian.Jumlah penduduk Indonesia yang terbesar di ASEAN ini akan menjadi sasaran pemasaran berbagai barang, jasa, dan investasi tetapi UMKM masih lemah dalam akses terhadap modal kerja atau kredit usaha, hak kekayaan intelektual, deregulasi, fasilitas ekspor, manajemen usaha dan administrasi, serta kontinuitas pasokan bahan baku.

UMKM di Indonesia bisa dikembangkan dengan menggenjot pengembangan cluster UMKM melalui keterlibatan stakeholder/pihak swasta dan pemerintah dalam hal ini peranan 
akademisi sangat membantu untuk mempersiapkan UMKM dalam menghadapi ASEAN ECONOMIC COMMUNITY 2015 dengan memberikan pelatihan-pelatihan kewirausahaan yang dilakukan secara intensif.

Dari perkembangan kontribusi PDB pada usaha mikro, kecil dan menengah terlihat peningkatan perkembangan dari tahun ke tahun. Pada tahun 2010, PDB usaha mikro, kecil dan menengah meningkat $0,59 \%$ dari $56,53 \%$ pada tahun 2009 menjadi $57,12 \%$ pada tahun 2010, sedangkan pada tahun 2011 meningkat sebesar $0,83 \%$ menjadi 57,94\% dan pada tahun 2012 terjadi peningkatan sebesar 1,14\% menjadi 59,08\%. Ini menunjukkan terjadi pertumbuhan UMKM secara berkelanjutan di Indonesia. Implementasi Masyarakat Ekonomi ASEAN yang diberlakukan tahun ini mempunyai tujuan bersama dalam meningkatkan instumen ekonomi Negara-negara ASEAN, MEA terwujud dari keinginan untuk menjadi kawasan Negara-negara untuk mewujudkan ASEAN menjadi kawasan perekonomian yang solid dan diperhitungkan dalam perekonomian internasional. Para Pemimpin ASEAN telah sepakat untuk mewujudkan MEA tahun 2015 dengan 4 pilar yaitu:

a. Pasar Tunggal dan basis produksi

b. Kawasan ekonomi berdaya saing tinggi

c. Kawasan dengan pembangunan ekonomi yang setara

d. Kawasan yang terintegrasi

Dengan adanya MEA, tujuan yang ingin dicapai adalah adanya aliran bebas barang, jasa dan tenaga kerja yang terlatih (skilled labour) serta aliran investasi yang lebih bebas. Dalam penerapannya MEA akan menerapkan 12 sektor prioritas yaitu: Perikanan, e-travel, e-ASEAN, automotif, logistik, Industri ber basis kayu, Industri berbasis karet, furniture, makanan dan minuman, tekstil serta kesehatan. Namun menurut SKKNI (Standar Kompetensi Kerja Nasional Indonesia), LSP (Lembaga Sertifikasi Profesi) dan MRA (Mutual Recognition Arangement), Indonesia siap dengan 3 sektor yang paling siap utnuk menyambut MEA yaitu: sektor pariwisata mebel, dan sektor tekstil. Bagi Indonesia MEA, pembentukan MEA merupakan tantangan yang tidak hanya bersifat internal di dalam negeri tetapi terlebih lagi persaingan dengan sesama Negara ASEAN dan Negara lain seperti Tiongkok dan India.Persaingan yang ketat akan mempunyai dampak pada harga yang kompetitif, bukan hanya komoditi berupa produk/jasa unggulan tetapi sektor UMKM karena kesamaan karaktersitik dari produk. Jumlah UMKM yang besar ini bukanlah suatu keunggulan bagi Indonesia jika tidak didukung oleh faktor produksi yang ada seperti Alam.

Modal, Tenaga kerja, Skill dan, adanya Kualitas Sumber Daya Manusia. Ada beberapa hal yang menghambat kualitas SDM Indonesia khususnya dalam UMKM yaitu; Pendidikan, Pengetahuan Tehnologi dan Komunikasi. Beberapa UMKM dinilai memiliki potensi pasar lokal sangat besar di tengah era perdagangangan MEA 2015.Namun untuk mampu bersaing, diperlukan inovasi, pemasaran serta penguasaan bahasa inggris yang baik. Saat ini yang menjadi hambatan dalam memasuki bisnis internasional adalah:

a. Batasan kuota dan tarif bea masuk

b. Perbedaan bahasa, sosial budaya/cultural:

c. Kondisi politik dan hukum/perundan-undangan:

d. Perbedaan Mata Uang Antarnegara

e. Kualitas Sumber Daya yang Rendah

f. Pembayaran Antar negara Sulit dan Risikonya Besar 
Ada beberapa hal yang menjadi pertimbangan mengapa para UMKM harus menguasai kemampuan bahasa yaitu:

1. Pelanggan yang dilayani oleh UMKM bukan berasal dari Indonesia saja, namun juga mencakup Negara-negara di ASEAN.Hal ini tentu menuntut para pelaku UMKM Indonesia untuk mampu menguasai bahasa inggris dengan baik agar dapat memberikan pelayanan yang maksimal sesuai dengan kebutuhan pasar.

2. Adanya persaingan usaha dan tenaga kerja yang semakin kompetitif untuk merebut peluang pasar yang ada. Para pelaku UMKM tidak hanya mengandalkan pelanggan local dari Indonesia serta menggunakan strategi bertahan. Para pelaku UMKM harus bisa semakin kompetitif mengembangkan usaha dan memanfatkan peluang yang ada.

3. Perkembangan Tehnologi dan Informasi yang sudah tentu dalam bahasa inggris menuntut para pelaku UMKM untuk bisa menguasai bahasa inggris guna mempelajari dan memanfaatkan tehnologi dan informasi dalam membantu perkembangan usaha yang dimiliki.

Dengan penguasaan bahasa inggris ini diharapkan masyarakat Indonesia maupun pelaku UMKM mempunyai bargaining power yang lebih besar. Tentunya belajar bahasa inggris memerlukan waktu yang tidak sebentar dan biaya yang tidak sedikit, selain itu juga harus dilatih secara konsisten tetapi setelah dapat menguasai dan lancar berbahasa inggris maka akan terasa manfaatnya.

Bahasa inggris merupakan bahasa internasional yang berfungsi sebagai alat komunikasi bagi orang-orang diseluruh dunia. Kemampuan berkomunikasi dengan bahasa Inggris dapat digunakan dalam berbagai aspek kehidupan seperti dalam aspek ekonomi, sosial, budaya, pendidikan, hukum, dan lainnya. Berdasarkan latar belakang diatas, maka yang akan menjadi dalam pelaksanaan kegiatan pelatihan tersebut adalah

a. Bagaimana metode pelaksanaan pelatihan tersebut dilaksanakan secara efektif?

b. Bagaimana korelasi dari kegiatan pelatihan tersebut dengan pelaksanaan ekspor yang dilaksanakan oleh para UMKM?

c. Hasil output yang akan diperoleh dari pelaksanaan pelatihan untuk para UMKM

Penelitian ini mempunyai beberapa tujuan antara lain:

a. Untuk mempelajari tentang persiapan dari UMKM dalam mengahadapi pasar bebasa ASEAN melalui program pelatihan Bahasa Inggris

b. Untuk mengetahui adanya hubungan atau korelasi terhadap pengaruh sebelum diadakan program pelatihan dan setelah diadakan program pelatihan bahasa inggris bagi para UMKM di daerah Tanggerang

c. Untuk mengetahui pengaruh korelasi terhadap hasil penjualan yang dilakukan oleh para UMKM didaerah Tanggerang sebelum dan sesudah mengikuti pelatihan bahasa Inggris.

Bahwa penulisan ini mempunyai pentingnya manfaat penelitian ini yaitu untuk:

a. Untuk mengetahui seberapa besar pengaruh pelatihan yang dilaksanakan sebelum dan sesudah peserta mengikuti pelatihan bagi para UMKM.

b. Untuk mengetahui seberapa besar efektivitas yang dilaksanakan melalui kegiatan pelatihan bahasa inggris bagi para UMKM. 
c. Untuk mengetahui hasil yang diperoleh dari hasil penelitian ini terhadap kegiatan pelaksankaan ekspor yang dilaksanakan oleh para Usaha Mikro Kecil Menengah (UMKM)

\section{KAJIAN PUSTAKA DAN PENGEMBANGAN HIPOTESIS}

Pada umumnya setiap organisasi sering terjadi suatu kesenjangan antara kebutuhan akan promosi tenaga kerja yang diharapkan oleh organisasi dengan kemampuan tenaga kerja dalam merespon kebutuhan, organisasi perlu melakukan suatu upaya untuk menjembatani kesenjangan ini. Salah satu cara yang dapat dilakukan organisasi adalah melalui program pelatihan. Melalui program pelatihan diharapkan seluruh potensi yang dimiliki dapat ditingkatkan sesuai dengan keinginan organisasi atau setidaknya mendekati apa yang diharapkan oleh organisasi. Berikut ini penjelasan beberapa ahli mengenai pengertian pelatihan:

Menurut Jan Bella dalam buku Manajemen Sumber Daya Manusia karangan Hasibuan (2003)

"Pendidikan dan Latihan sama dengan pengembangan yaitu merupakan proses peningkatan keterampilan kerja baik teknis maupun manajerial. Pendidikan berorientasi pada teori, dilakukan dalam kelas, berlangsung lama, dan biasanya menjawab why Latihan berorientasi pada praktek, dilakukan di lapangan, berlangsung singkat, dan biasanya menjawab how." Menurut Pangabean (2004) "Pelatihan dapat Didefinisikan sebagai suatu cara yang digunakan untuk memberikan atau meningkatkan keterampilan yang dibutuhkan untuk melaksanakan pekerjaan sekarang, Sedangkan pendidikan lebih berorientasi kepada masa depan dan lebih menekankan pada peningkatan kemampuan seseorang untuk memahami dan menginterpretasikan pengetahuan".

Berdasarkan pengertian diatas dapat ditarik kesimpulan bahwa pelatihan adalah suatu kegiatan untuk memperbaiki kemampuan dan meningkatkan kinerja karyawan dalam melaksanakan tugasnya dengan cara peningkatan keahlian, pengetahuan, keterampilan, sikap dan perilaku yang spesifik yang berkaitan dengan pekerjaan.

Tujuan pelatihan menurut Pangabean (2004), pada umumnya, pelatihan dilakukan untuk memenuhi kebutuhan terhadap karyawan, perusahaan, dan konsumen, adapun tujuan dari pelatihan adalah:

a. Memberikan keterampilan dan pengetahuan yang diperlukan karyawan.

b. Meningkatkan moral karyawan. Dengan keterampilan dan keahlian yang sesuai dengan pekerjaannya mereka akan antusias untuk menyelesaikan pekerjaanya dengan baik.

c. Memperbaiki kinerja. Karyawan yang bekerja secara tidak memuaskan karena kekurangan keterampilan dapat diminimalkan melalui program pelatihan dan pengembangan.

d. Membantu karyawan dalam menghadapi perubahan-perubahan, baik perubahan struktur organisasi, teknologi, maupun sumber daya manusia.

e. Melalui pelatihan dan pengembangan karyawan diharapkan dapat secara efektif menggunakan teknologi baru. Manajer di semua bidang harus secara konstan 
mengetahui kemajuan teknologi yang membuat organisasi berfungsi secara lebih efektif.

f. Peningkatan karier karyawan. Dengan pelatihan dan pengembangan kesempatan untuk meningkatkan karier menjadi besar karena keahlian, keterampilan dan prestasi kerja lebih baik.

g. Meningkatkan jumlah balas jasa yang dapat diterima karyawan. Dengan pelatihan dan pengembangan, maka keterampilan semakin meningkat dan prestasi kerja semakin baik dan gaji juga akan meningkat karena kenaikan gaji didasarkan prestasi.

\subsection{Pengertian Bahasa}

Menurut (Bloch and Trager, dikutip Lyons 1981: 4)

Language is a system of arbitrary vocal symbols by means of which a social group cooperates. Sedangkan (Hall, dikutip Lyons 1981: 4) Language is the institution whereby humans communicate and interact with each other by means of habitually used oral-auditory arbitrary symbols.

Jika disimpulkan dari pengertian diatas dapat ditarik kesimpulan bahwa bahasa adala alat dimana manusia dapat melakukan berkomunikasi dan berinteraksi satu dengan yang lainnya melalui lambang/simbol.

\subsection{Pentingnya Belajar Bahasa Inggris}

Era kemajuan ilmu pengetahuan dan teknologi yang semakin pesat, semakin membuka kesempatan kesempatan untuk berkomunikasi secara internasional. Pelaksanaan pasar bebas menuntut Bangsa Indonesia memiliki kompetensi yang kompetitif dalam berbagai bidang. Indonesia tidak bisa lagi hanya mengandalkan sumber daya alam dan kemampuan fisik untuk mencapai kesejahteraan bangsanya tetapi harus lebih mengandalkan sumber daya manusia yang profesional. Salah satu persyaratan mutlak untuk mencapainya adalah dengan memiliki kemampuan berkomunikasi yang baik.

Alat komunikasi yang utama di seluruh dunia adalah bahasa. Bahasa merupakan suatu sistem lambang berupa bunyi, bersifat abitrer, digunakan oleh masyarakat untuk bertutur, bekerja sama, berkomunikasi, dan untuk mengidentifikasi diri (Keraf \& Chaer, 2006; 1). Tanpa bahasa manusia tidak dapat berkomunikasi untuk menyampaikan pikiran dan perasaannya. Penguasaan bahasa secara terpadu (integrated) meliputi keterampilan berbicara, mendengar, membaca dan menulis merupakan bagian yang penting untuk dipelajari.

Pembelajaran bahasa menjadi semakin penting untuk dapat berkomunikasi dengan baik pula. Pengertian berkomunikasi yang dimaksudkan adalah memahami dan mengungkapkan informasi, pikiran, perasaan serta mengembangkan ilmu pengetahuan, teknologi dan budaya dengan menggunakan bahasa. Kemampuan berkomunikasi pada level selanjutnya dalam pengertian yang utuh adalah kemampuan berwacana.

Tidak dapat dipungkiri bahwa sampai saat ini bahasa Internasional pertama yang banyak digunakan adalah bahasa Inggris. Bahasa Inggris diajarkan secara luas di berbagai negara di dunia ini. Menurut Richards \& Rodger, 1986, banyak penduduk di berbagai negara memakai bahasa Inggris sebagai alat komunikasi dalam berbagai pertemuan penting tingkat 
internasional. Penguasaan bahasa Inggris menjadi sangat penting karena hampir semua sumber informasi global dalam berbagai aspek kehidupan menggunakan bahasa ini. Crystal $(2000 ; 1)$ menyebutkan bahwa bahasa Inggris adalah bahasa Global. Pernyataan ini mewakili makna bahwa bahasa Inggris digunakan oleh berbagai bangsa untuk berkomunikasi dengan bangsa di seluruh dunia. Jadi, bahasa Inggris adalah salah satu bahasa Internasional ekaligus bahasa global.

\subsection{Pengertian UMKM}

Sesuai dengan Undang- Undang Nomor 20 Tahun 2008 tentang Usaha Mikro, Kecil dan Menengah (UMKM):

- Usaha Mikro adalah usaha produktif milik orang perorangan dan/atau badanusaha perorangan yang memenuhi kriteria Usaha Mikro sebagaimana diatur dalam Undang-Undang ini.

- Usaha Kecil adalah usaha ekonomi produktif yang berdiri sendiri, yang diatur oleh dilakukan oleh orang perorangan atau badan usaha yang bukan merupakan anak perusahaan atau bukan cabang perusahaan yang dimiliki, dikuasai, atau menjadi bagian baik langsung maupun tidak langsung dari usaha menengah atau usaha besar yang memenuhi kriteria Usaha Kecil Kriteria UMKM berdasarkan jumlah asset dan omzet

\begin{tabular}{|l|l|l|}
\hline Jenis usaha & Asset & Omset \\
\hline Usaha mikro & Max 50jt & Maks 300juta \\
Usaha kecil & Besar dari 50jt-500jt & Besar dari 300juta-3M \\
Usaha menengah & Besar dari 500jt-10M & Besar dari 2,5M-50M \\
\hline
\end{tabular}

Berdasarkan UU.no 20 tahun 2008 di atas jelas menunjukkan perbedaan yang cukup besar baik dari segi aset ataupun omset antara usaha mikro dengan kecil dan usaha kecil dengan menengah.

\subsection{Pengertian Masyarakat Ekonomi ASEAN}

Menurut situs resmi ASEAN, MEA adalah bentuk integrasi ekonomi ASEAN dalam artian adanya sistem perdagaangan bebas antara AEC akan menjadi pasar tunggal untuk barang dan jasa untuk meningkatkan jaringan produksi di wilayah ASEAN dan kapasitas ASEAN sebagai pusat produksi global. Untuk mengetahui bagaimana posisi Indonesia diantara Negara anggota ASEAN lainnya dalam menghadapi AEC maka di gunakan index. salah satu hasil survey dari Logistic Performace Index (LPI) yang dilakukan Bank Dunia tahun 2014 menduduki perinkat 53 yang yang berarti lebih rendah dibandingkan Vietnam (dengan peringkat ke 48), lihat tabel 3 . Adapun faktor-faktor yang mempengaruhi peringkat biaya logistic diantaranya kepabeanan, infrastruktur, pengirimin internasional, kompetensi logistik, biaya logistik domestic dan ketepatan waktu. 
Tabel 3: The Top 10 Lower middle-income performance on the $2014 \mathrm{LPI}^{\star}$ )

\begin{tabular}{|c|c|c|c|c|c|c|c|c|c|}
\hline \multirow[b]{2}{*}{ Economy } & \multicolumn{3}{|c|}{2014 LPI } & \multicolumn{3}{|c|}{2012 LPI } & \multicolumn{3}{|c|}{2010 LPI } \\
\hline & Rank & Score & $\begin{array}{c}\% \text { of } \\
\text { highest } \\
\text { performer }\end{array}$ & Rank & Score & $\begin{array}{c}\% \text { of } \\
\text { highest } \\
\text { performer }\end{array}$ & Rank & Score & $\begin{array}{c}\% \text { of } \\
\text { highest } \\
\text { performer }\end{array}$ \\
\hline Vietnam & 48 & 3.15 & 69.0 & 53 & 3.00 & 64.1 & 53 & 2.96 & 63.1 \\
\hline Indonesia & 53 & 3.08 & 66.7 & 59 & 2.94 & 62.2 & 75 & 2.76 & 56.5 \\
\hline India & 54 & 3.08 & 66.6 & 46 & 3.08 & 66.4 & 47 & 3.12 & 67.9 \\
\hline Philippines & 57 & 3.00 & 64.2 & 52 & 3.02 & 64.8 & 44 & 3.14 & 68.8 \\
\hline Ukraine & 61 & 2.98 & 63.3 & 66 & 2.85 & 59.3 & 102 & 2.57 & 50.6 \\
\hline Egypt, Arab Rep. & 62 & 2.97 & 63.0 & 57 & 2.98 & 63.3 & 92 & 2.61 & 51.8 \\
\hline El Salvador & 64 & 2.96 & 62.8 & 93 & 2.60 & 51.2 & 86 & 2.67 & 53.7 \\
\hline Pakistan & 72 & 2.83 & 58.5 & 71 & 2.83 & 58.4 & 110 & 2.53 & 49.1 \\
\hline Nigeria & 75 & 2.81 & 57.9 & 121 & 2.45 & 46.3 & 100 & 2.59 & 51.0 \\
\hline Guatemala & 77 & 2.80 & 57.6 & 74 & 2.80 & 57.7 & 90 & 2.63 & 52.4 \\
\hline
\end{tabular}

Source: Logistics Performance Index 2010, 2012, and 2014

\section{METODOLOGI PENELITIAN}

Untuk dapat diketahui pasar, para pelaku UMKM harus memudahkan target pelanggan untuk menemukan mereka (buyers). Keberadaan di dunia maya harus dilakukan, mulai dari memiliki website, aktif di media sosial, hingga memasang info produk dan perusahaan di direktori-direktori online. Bahasa Inggris harus dikuasai agar komunikasi tidak terkendala. Lebih baik lagi jika juga menguasai bahasa tiap negara. Persiapan harus dilakukan sejak dini agar UMKM kita tidak hanya akan dapat bertahan di negeri sendiri, tetapi juga dapat bersaing menjadi pemain utama se-Asia Tenggara.

Penelitian ini untuk membuktikan bahwa kedua variable akan mempunyai dampak terhadap sebelum dan sesudah pelatihan bahasa inggris untuk para UMKM

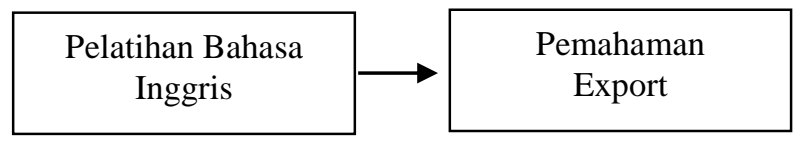

Gambar 1: Hubungan Indikator terhadap pelatihan bahasa inggris mempunyai pengaruh terhadap

\subsection{Alur Penelitian} peluang Ekspor.

Diagram alur penelitian ini mengacu pada metode kuantitatif yang di analisa dengan menggunakan analisa chi square/Uji Hipotesis

Metode Chi Square berguna untuk menguji hubungan atau pengaruh dua buah variabel nominal dan mengukur kuatnya hubungan antara variabel yang satu dengan variabel nominal lainnya ( $\mathrm{C}=$ Coefisien of contingency).

Dari metode chi square diharapkan dapat menemukan perbedaaan antara sebelum dan sesudah melakukan kursus bahasa inggris terhadap ekspor yang akan dilaksanakan oleh para UMKM. 
Metodelogi ini diaplikasikan guna menjawab pertanyaan dari penelitian yang dilakukan oleh penulis dengan rincian sebagai berikut:

- Apakah terdapat perbedaan sebelum pelaksanaan peserta mengikuti pelatihan bahasa inggris terhadap dari segi pemahaman dan peluang ekspor kepada para UMKM

- Apakah terdapat perbedaan sesudah pelaksanaan peserta mengikuti pelatihan bahasa inggris terhadap segi pemahaman dan peluang ekspor kepada para UMKM

\subsection{Populasi dan Sampel}

Penelitian ini dilakukan terhadap UMKM yang mempunyai kesulitan dalam bahasa inggris berupa: writing (menulis), speaking (berbicara), reading (membaca) dan listening (mendengar) serta mempunyai kekurangan pengetahuan terhadap kegiatan ekspor barang baik berupa masalah yang berkaitan marketing (pemasaran) dan packaging (pengepakan). Sampel penelitian ini diambil dari UMKM di wilayah Tanggerang dengan mengambil 4 kecamatan sebanyak 20 UMKM.

\subsection{Instrumen Penelitian}

Instrument yang digunakan dalam penelitian ini adalah kuesioner sebagai sebagai sumber informasi tentang kesiapan UMKM dalam menghadapi MEA dan kemampuan pemahaman Bahasa Inggris dan strategi Pemasaran ekspor melalui metode survey dan memberikan pelatihan bahasa inggris selama 30 jam. Seluruh butir pertanyaan atau pernyataan diukur berdasarkan kuesioner dan hasil pre test dan post test dimana pengumpulan data dilaksanakan melalui cara penyebaran Kuesioner dengan memberikan angket /daftar pertanyaan kepada para 20 Usaha Mikro Kecil Menengah yang berada di 4 Kecamatan wilayah Tanggerang secara sampling

\subsection{Validitas \& Reliabilitas Instumen Penelitian}

Untuk menganalisa data menggunakan tehnik prosentase dan disajikan dalam diagram deskritif dan menggunakan bentuk metode terhadap hasil sebelum latihan dan sesudah latihan bahasa inggris yang disajikan dalam perbandingan terhadap hasil uji beda/ChiSquare dari metode penyebaran kuesioner.

\section{HASIL DAN PEMBAHASAN}

MEA atau ASEAN Economy Community (AEC) dapat memberikan peluang bagi puluhan juta UMKM di Indoneia untuk memperluas pasar mereka. beberapa manfaat yang bisa di dapat oleh UMKM yaitu:

- UMKM dapat mengetahui kebutuhan dan keinginan pasar ASEAN

- Memasarkan produk dan menjual produk ke berbagai pelanggan dan Negara di ASEAN

- Mendapatkan investor yang bagian dari Negara-negara Angota ASEAN

- Mampu melakukan negosiasi dengan pembeli (buyer) dari Negara-Negara Anggota ASEAN.

- Melakukan deal/kerjasama yang menguntungkan dengan Negara-negara anggota ASEAN 
Peran UMKM ...

Suatu hal yang menjadi kelemahan penguasaan bahasa dalam menghadapi Masyarakat Ekonomi ASEAN in adalah tantangan yang harus dihadapi. Kendala ini adalah bagaimana meningkatkan kemampuan ber-bahasa inggris dan pengetahuan ekspor bagi para UMKM, mengingat selama ini mereka hanya beracuan kepada para freight forwader/jasa logistic agent pengurusan untuk barang yang akan diekspor/import ke luar negeri karena bila kita melihat dari sisi valuta asing akan memberikan keuntungan yang besar dan pemerintah sedang mendorong utnuk menggalakan produk local. Menurut data yang dikeluarkan oleh salah satu lembaga pendidikan bahasa asing , EF English Proficiency Index, menunjukan Indoensia menempati urutan ke 27 dari 52 negara di dalam hal index kemampuan berbahasa Inggris. (Sementara Negara tetangga dengan kategori rata, Untuk Singapura Negara tetangga berada di urutan 12 (dengan score 58.65) dan Malaysia urutan 13 (score 57.95). Dari hasil survey tersebut dapat diketahui bahwa kemampuan bahasa inggris masyarakat Indonesia masih sangat lemah.Indonesia. Indonesia tertinggal jauh dari Singapura dan Malaysia yang mempunyai kemampuan berbahasa inggris lebih baik. Melalui penelitian ini, memperoleh data berdasarkan kuesioner di UMKM di Tanggerang bahwa hamper lebih $90 \%$ para UMKM mempunyai dampak pentingnya bahasa inggris untuk menghadapi tantangan Masyarakat Ekonomi ASEAN 2015.(Terlampir dalam tabel 4.2)

Tabel 4.1

Hasil Kuesioner terhadap pentingnya bahasa Inggris

\begin{tabular}{|l|l|l|l|l|}
\hline & $\begin{array}{l}\text { Pentingnya } \\
\text { Bahasa } \\
\text { Inggris }\end{array}$ & $\begin{array}{l}\text { Tidak } \\
\text { Penting }\end{array}$ & $\begin{array}{l}\text { Tidak } \\
\text { tahu }\end{array}$ & Total \\
\hline Jumlah Kuesioner & 32 & 5 & 3 & 40 \\
\hline Prosentase & $95 \%$ & $4 \%$ & $1 \%$ & $100 \%$ \\
\hline
\end{tabular}

Sumber: Pengolahan data 2015

Dalam penelitian ini mendapatkan 5 kecamatan dari total kuesioner yang disebar sebanyak 50 kuesioner dan terdapat 95\% menyatakan bahwa kemampuan bahasa inggris sangat dibutuhkan sedangkan sisa nya sebnyak 4\% mereka berpendapat tidak penting bahasa inggris karena mereka kurang memahami tentang adanya keberadaan MEA (Masyarakat Ekonomi ASEAN 2015 sedangkan 1 \% UMKM tidak mengisi kuesioner yang di berikan.

Untuk melengkapi penelitian ini, penulis juga mendapatkan data bahwa total kecamatan yang dibawah naungan Dinas Koperasi \& UMKM Kabupaten Tanggerang sebanyak 29 Kecamatan dengan total UMKM sebanyak 3500 UMKM, tetapi penulis hanya mengambil data secara random dengan berdasarkan wilayah yang mempunyai potensi untuk ekspor seperti Kecamatan Teluk Naga, Kosambi, Panongan, Paku Haji, dan Kemiri. Jenis usaha dari UKM tersebut beragam seperti Topi Bambu, Tas, Sepatu, Dompet, Kerajinan membuat meja dan alat praga untuk anak anak TK, Makanan dan lainnya.

\subsection{Pelaksanaan Kegiatan Pelatihan}

Kegiatan Pelatihan bahasa inggris dilaksanakan selama 30 jam dengan metode tatap muka dan evaluasi dengan waktu 120 menit dimana 90 menit dikelas untuk pembahasan 
materi dan 30 menit untuk evaluasi terhadap materi pengajaran yang diberikan sebelumnya. Kegiatan dilaksanakan mulai dari tanggal 4 juni sampai dengan 4 Agustus 2015, waktu pelaksanaan 1 minggu 2x pertemuan (selasa dan kamis) kegiatan ini sempat break/sitirahat dikarenakan liburan idul fitri. Prosentase dari tabel diatas bahwa kegiatan lebih difokuskan kepada writing (menulis) dikarenakan para UMKM akan melakukan kegiatan ekspor melalui email dan penekanan kepada pengajaran English for business. Selain diberikan materi writing, UMKM juga diberikan grammar (tata bahasa). Grmmar sebagai dasar untuk menulis agar dalam susunan atau tata bahasa dalam berkoresponden dengan buyers dapat benar dan tepat.

\subsection{Hasil Pre-test}

Adapun hasil dari Pre-test yang dilaksankan selama 100 menit dengan bentuk soal pilihan ganda/multiple choice, dan waktu yang diberikan masing-masing soal sebagai berikut:

Tabel 4.2

Jenis Pre Test untuk UMKM

\begin{tabular}{|l|l|l|l|}
\hline No & Soal Ujian & $\begin{array}{l}\text { Jumlah } \\
\text { Soal }\end{array}$ & Lama Test \\
\hline 1 & Listening & 20 & 45 menit \\
\hline 2 & Reading \& Grammar & 30 & 55 menit \\
\hline & Total & 50 & 100 menit \\
\hline
\end{tabular}

Dari hasil tabel diatas dijelaskan tentang pengertian dari jenis soal ujian:

- $\quad$ Listening adalah kerampilan menyimak untuk memahami makna atau maksud dari ucapan seseorang baik dalam bentuk kata, frasa, kalimat yang sederhana, sampai gabungan kompleks yang berasal dari Audio/Video seperti: TV, radio, Kaset, dll.

- Reading adalah ketrampilan mendeskripsikan sesuatu secara detail dengan berupa tulisan dalam bentuk soal cerita/kasus.I

- Grammar adalah kumpulan kaidah tentang struktur tata bahasa tata bahasa.

Dari hasil kuesioner yang disebar oleh penulis sebanyak 20 UMKM yang berasal dari beberapa kecamatan di kota Tanggerang, diperoleh data bahwa 30 responden memberikan pilihan bahwa bahasa inggris sangat penting untuk menghadapi Masyarakat Ekonomi ASEAN, tetapi yang hadir dan mengirimkan peserta dari UMKM untuk mengikuti pelatihan bahasa inggris ini hanya 20 UMKM, berikut adalah hasil Pre test yang dilaksanakan tanggal 4 Juni 2015. Hasil test ini akan menjadi bagian untuk evaluasi kemampuan bahasa inggris yang akan dilaksanakan selama total 46 jam setiap 2x pertemuan setiap minggu selama 2 jam untuk 16x pertemuan.

Adapun data dari hasil test sebelum dan sesudah menunujukan bahwa nilai total sebelum kursus untuk (listening \& grammar) antara 50 - 70 sementara nilai setelah kursus untuk total reading/grammar diketahui 77 - 90, ini menujukan bahwa peserta memiliki peningkatan untuk nilai bahasa inggris tetapi mereka ada keinginan untuk dapat berbahasa inggris dan kepercayaan untuk berkorespondesi dengan menggunakan online guna menghadapi pasar perdagangan bebas ASEAN 2015. 
Peran UMKM ...

Hipotesis
$\mathrm{H}_{0}: \mu_{1}=\mu_{2}$
$\mathrm{H}_{1}: \mu_{1} \neq \mu_{2}$
$\alpha=0,05$
$\overline{\mathrm{x}}_{1}=63,3 ; \overline{\mathrm{x}}_{2}=84,35$
$\sigma_{1}=5,302 ; \sigma_{2}=4,075$

Dari hasil ini dapat diketahui $t_{\text {hitung }}=-12,574<-2,093=t_{\text {tabel }}$ maka $\mathrm{H}_{0}$ ditolak

\subsection{Output SPSS dan Analisis Data}

Pada bagian pertama terlihat ringkasan dari kedua sampel. Untuk nilai ujian sebelum kursus memiliki nilai rata-rata 63,3 dari total keseluruhan 20 nilai dari peserta UMKM. Sedangkan nilai ujian setelah kursus memiliki nilai rata-rata 84,35 dari total keseluruhan 20 data. Selain itu, pada tabel ini juga dapat diketahui nilai standard deviation dan standard error mean dari masing-masing variabel.

Paired Samples Statistics

\begin{tabular}{|ll|l|l|l|l|}
\hline & & & $\begin{array}{l}\text { Std. } \\
\text { Std. } \\
\text { Deviation }\end{array}$ & $\begin{array}{l}\text { Error } \\
\text { Mean }\end{array}$ \\
\hline Pair 1 & nilai_ujian_sebelum & 63.30 & 20 & 5.302 & 1.186 \\
& nilai_ujian_sesudah & 84.35 & 20 & 4.705 & 1.052 \\
\hline
\end{tabular}

Paired Samples Correlations

\begin{tabular}{|c|c|c|c|}
\hline & $\mathrm{N}$ & Correlation & Sig. \\
\hline $\begin{array}{l}\text { Pai nilai_ujian_sebelum \& } \\
r 1 \text { nilai_ujian_sesudah }\end{array}$ & 20 & -.116 & .626 \\
\hline
\end{tabular}

Pengambilan keputusan:

Berdasarkan perbandingan $t_{\text {hitung }}$ dengan $t_{\text {tabel: }}$ :

- Jika thitung berada dalam rangettabel, maka $\mathrm{H}_{0}$ diterima

- Jika $t_{\text {hitung }}$ berada di luar ranget tabel, maka $\mathrm{H}_{0}$ ditolak

$t_{\text {hitung }}$ dari output adalah $-12,574$

$$
t_{\text {tabel }}=t_{(\alpha / 2 ; n-1)}=t_{(0,05 / 2: 20-1)}=t_{(0,025 ; 19)}=2,093
$$

Karena $t_{\text {hitung }}=-12,574<-2,093=t_{\text {tabel }}$ maka $\mathrm{H}_{0}$ ditolak.

Ini dapat dikatakan bahwa pelaksanaan program pelatihan bahasa inggris efektif untuk diterapkan bagi UMKM di Tanggerang sehingga dapat meningkatkan kepercayaan diri untuk menghadapi ASEAN ECONOMIC COMMUNITY 2015. 


\section{KESIMPULAN}

a. Disimpulkan bahwa pelaksanaan dari program pelatihan dapat diketahui bahwa untuk nilai ujian sebelum remediasi, pada pelatihan bahasa inggris bagi para UMKM memiliki nilai rata-rata 63,3 . Untuk nilai ujian setelah remediasi, mahasiswa memiliki nilai ratarata 84,35 dari total keseluruhan 20 data. Sedangkan nilai standard deviation 7.487 dan standard error mean 1.626

b. Program pelatihan untuk Bahasa Inggris selama $15 x$ pertemuan dengan waktu pertemuan 2 jam telah berjalan dengan baik dan sangat efektif, hal ini terlihat dari hasil test sebelum pelaksanaan dan setelah pelaksanaan untuk kursus bahasa Inggris.

\section{DAFTAR PUSTAKA}

Astuti Purnamawati. (2013). Dasar-dasar Ekspor Teori, Praktik dan Prosedur. Penerbit UPP, STIM YKPIN,

Indarto dan Subroto J. (2007). Ekonomi Kontekstual

Jan Bella, Hasibuan. (2003). Manajemen Sumber Daya "Pendidikan dan Latihan"

Undang-Undang Nomor 20 Tahun 2008 tentang Usaha Mikro, Kecil dan Menengah (UMKM): Pangabean 2004 Manajemen Sumber Daya "Pendidikan dan Latihan"

J. Soedradjad Djiwandono. Indonesia, MEA 2015 dan Globalisasi, Butir-butir Presentasi pada Kuliah Umum Pada Fakultas Ekonomi, Unika ATMA JAYA, Jakarta 17 November 2014

International Journal Preparing Thai Students' English for the ASEAN Economic Community: Some Pedagogical Implications and Trends Daranee Choomthon Mari Elka Pangestu Minister of Trade of the Republic of Indonesia OMPETITIVENESS TOWARDS ASEAN ECONOMIC COMMUNITY Journal of Indonesian Economy and Business Volume 24, Number 1, 2009, 22 - 32

Sarah Anabarja Jendala dan Tantangan Indonesia dalam Mengimplementasikan ASEAN Free Trade 